\title{
MODEL PEMBERDAYAAN EKONOMI KELUARGA MISKIN TERINTEGRASI DENGAN WIRAUSAHA PRODUK IKAN
}

\author{
Marwanti, Siti Hamidah, Yuriani \\ Universitas Negeri Yogyakarta \\ email: marwanti_ptbb@yahoo.com
}

\begin{abstract}
Abstrak: Model Pemberdayaan Ekonomi Keluarga Miskin Terintegrasi dengan Wirausaha Produk Ikan. Penelitian ini bertujuan untuk: (1) menemukan permasalahan ekonomi dan nonekonomi yang menjadi kendala keluarga miskin di wilayah Kretek Bantul Yogyakarta; (2) menemukan cara mengembangkan model pemberdayaan ekonomi keluarga miskin terintegrasi dengan wirausaha produk ikan sehingga dapat meningkatkan sikap dan keterampilan wirausaha keluarga di Kretek Bantul; dan (3) menghasilkan model pemberdayaan keluarga miskin yang berupa buku panduan dan perangkat pembelajaran yang praktis untuk dilaksanakan. Penelitian ini menggunakan pendekatan kualitatif dan kuantitatif. Pengembangan model menggunakan pendekatan R \& D dari Borg \& Gall yang diringkas menjadi 3 konstruk model studi pendahuluan, pengembangan model, dan pengujian model, yang tertata dalam 2 tahap. Tahap pertama, menemukan permasalahan ekonomi dan nonekonomi yang menjadi kendala keluarga nelayan miskin, menemukan cara pemberdayaan ekonomi keluarga miskin, dan menghasilkan model pemberdayaan ekonomi keluarga miskin yang berupa buku panduan dan perangkat pembelajaran. Tahap kedua berupa implementasi model dan sosialisasi model dalam lingkup yang lebih luas.
\end{abstract}

Kata kunci: pemberdayaan ekonomi, terintegrasi, keluarga miskin, produk ikan

Abstrak: Economic Empowerment Model for Poor Families with Entrepreneurial Integrated Fish Products. This study aims to: (1) find economic and noneconomic issues that constrain poor families in the region Kretek Bantul, Yogyakarta; (2) find a way to develop models of economic empowerment of poor families is integrated with entrepreneurial fish products so as to improve the entrepreneurial attitude and skills of families in Kretek Bantul; and (3) produce models of empowerment of poor families in the form of guide books and learning tools that are practical to implement. This study uses qualitative and quantitative approaches. Development of a model using the approach R \& D from Borg \& Gall summarized into 3 construct a model: a preliminary study, development models, and testing models, which are arranged in two stages. The first stage, find economic and noneconomic issues that constrain poor fishing families, finding ways of economic empowerment of poor families, and result in the model of economic empowerment of poor families in the form of guide books and learning tools. The second phase in the form of implementation models and socialization models in a broader scope.

Kata kunci: Economic Empowerment, integrated, poor family, fish product 


\section{PENDAHULUAN}

Masalah kemiskinan merupakan masalah sosial laten yang memerlukan penanganan yang berkelanjutan. Hal ini terkait dengan upaya pengentasan kemiskinan yang telah dilakukan selama ini belum mampu mengurai secara tuntas bahkan gejalanya semakin meningkat sejalan dengan krisis multidimensional yang masih dihadapi bangsa Indonesia saat ini. Angka kemiskinan di DIY lebih tinggi dibandingkan dengan angka kemiskinan di tingkat nasional. Menurut susenas tahun 2012, angka kemiskinan DIY sebesar 15,59\%. Angka ini berada di atas angka rata-rata kemiskinan tingkat nasional yakni 11,66\%. Mengatasi masalah kemiskinan tidak hanya memberdayakan ekonomi keluarga, namun tetap memperhatikan dimensi lain yang bersifat nonekonomi. Seperti aspek soft skills antara lain menghilangkan rasa apatis dan rasa tak berdaya, menumbuhkan semangat kewirausahaan, komitmen, dan membangun tim kerja sebagai net working.

Indonesia adalah negara yang kaya dengan segala sumber daya alam yang tersedia secara melimpah termasuk sumber daya laut. DIY memiliki pantai yang cukup potensial sebagai sumber daya penghidupan bagi keluarga di sekitarnya. Pantai berada di sepanjang Laut Selatan mulai dari Kabupaten Kulon Progo, Bantul, dan Gunung Kidul dengan sumber daya laut yang sangat melimpah dan belum dimanfaatkan secara maksimal. Daerah Bantul sendiri menyumbang hasil laut sebesar 14,99\% dari hasil laut DIY (Pemerintah Kabupaten Bantul, 2012). Angka tersebut walaupun kecil perlu dimanfaatkan dengan maksimal agar bernilai lebih. Nilai lebih ini bila dikelola dengan benar akan berdampak pada peningkatan hasil laut dan peningkatan kemampuan keluarga nelayan dalam mengatasi hambatan-hambatan menuju keluarga yang berdaya. Harapannya sumber daya laut dapat memberi sumbangan pada pengembangan potensi keluarga nelayan sebagai aset negara.

Kretek merupakan salah satu kecamatan di Bantul dengan potensi laut, seperti Parangtritis, Pundong, dan Samas. Secara alami potensi ini dapat menjadi aset ketika penduduk pesisir memiliki kemampuan yang memadai. Pendidikan nonformal dipandang mampu menggerakkan partisipasi aktif dari keluarga nelayan dengan penekanan pada kekuatan dan potensi lokal. Dengan angka kemiskinan Bantul 14,27\%, maka program ketiga pemerintah kecamatan Kretek adalah mengatasi kemiskinan. Keluarga nelayan dapat dipandang sebagai keluarga miskin yang harus diberdayakan melalui program yang dicanangkan oleh pemerintah dengan pemanfaatan potensi lokal.

Keadaan tersebut perlu penanganan yang holistik melalui pendidikan nonformal untuk menjadikan sumber daya manusia sebagai aset atau modal bagi keluarga dan masyarakat. SDM adalah aset yang tidak bernilai, dapat dilipatgandakan, dan dikembangkan, bukan sebagai beban atau biaya. Dalam pandangan pendekatan pengembangan SDM: it assummes that expanded capabilities and opportunities for peaple will directly to improvements in operating effectiveness. That better people achive better result. Hal ini diilustrasikan: Give a porson a fish and you feed that person for a day. Teach a person to fish, and you feed that person for life (Davis \& Newstrom, 1996:12-13). Karenanya keluarga nelayan secara ekonomi dikembangkan potensinya agar pendapatannya meningkat dan secara mental harus dikuatkan 
soft skills-nya agar muncul jiwa wirausaha yang tangguh.

Langkah-langkah tersebut meliputi pengembangan kemampuan ataupun mendorong produktivitas melalui peningkatan keterampilan usaha yang secara terintegrasi dikembangkan soft skills-nya agar menjadi pendorong atau kekuatan diri meraih kemajuan yang berkelanjutan. Mereka harus dilibatkan dalam keseluruhan proses penanggulangan mulai dari perencanaan, pelaksanaan, pengawasan, evaluasi, hingga pengambilan keputusan. Dengan cara ini partisipasi aktif secara self direction akan sangat menentukan keberhasilan pemberdayaan ekonomi keluarga miskin Kecamatan Kretek Bantul Yogyakarta. Secara aktif mereka berusaha menolong diri mereka sendiri dan secara berkelanjutan akan berusaha meningkatkan diri secara lebih baik (empowering), dan berubah sebagai agen pembaruan komunitas mereka.

Melihat begitu luasnya permasalahan kemiskinan yang dihadapi oleh keluarga nelayan, menjadi tantangan bagi tiap keluarga untuk mengembangkan potensi lokal yang relevan dengan kebutuhan setiap karakter lokal pantai dan bagaimana mengiplementasikan secara terpadu antara teknologi produktivitas perikanan dengan soft skills. Oleh karena itu, diperlukan kajian rumusan dan implementasi pola pelatihan dan strateginya. Langkah awalnya adalah identifikasi permasalahan penguatan ekonomi yang relevan untuk komunitas keluarga miskin di Kretek kemudian dikembangkan bagaimana model pelatihan yang integratif. Urgensi penelitian ini bermaksud menemukan pola pendidikan nonformal integrasi untuk komunitas keluarga nelayan di Kretek yang terbukti efektif dan diharapkan dapat bermanfaat bagi dunia pendidikan secara praktis, khusunya bagi pendidikan masyarakat guna meningkatkan motivasi serta semangat masyarakat miskin sebagai peserta program pemberdayaan ekonomi terintegrasi keluarga miskin melalui wirausaha produk ikan. Selanjutnya masyarakat, khususnya masyarakat miskin menjadi lebih berdaya, lebih mandiri dan dapat meningkatkan pendapatan menuju kesejahteraan keluarga. Model pemberdayaan masyarakat ini diharapkan dapat diterapkan di berbagai daerah dengan memperhatikan potensi pendukung usaha bidang boga yang terdapat pada daerah tertentu.

Penyelenggaraan pendidikan nonformal adalah pendidikan berbasis masyarakat (community based education) yang merupakan tahapan pemberian peluang bagi setiap orang untuk memperkaya ilmu pengetahuan dan teknologi melalui pembelajaran seumur hidup. Munculnya paradigma pendidikan berbasis masyarakat dipicu oleh arus modernisasi yang menghendaki terciptanya demokratisasi dalam segala dimensi kehidupan manusia, termasuk di bidang pendidikan. Pendidikan berbasis masyarakat menjadi sebuah gerakan penyadaran masyarakat untuk terus belajar sepanjang hayat dalam mengisi tantangan kehidupan yang dinamis. Secara konseptual, pendidikan berbasis masyarakat adalah model penyelenggaraan pendidikan yang bertumpu pada prinsip "dari masyarakat, oleh masyarakat, dan untuk masyarakat". Hal ini sejalan dengan prinsip pembelajaran andragogi. Maliki (2010) menegaskan, andragogi adalah suatu model proses pembelajaran peserta didik yang terdiri atas orang dewasa. Androgogi disebut juga sebagai teknologi pelibatan orang dewasa dalam pembelajaran. 
Tujuan penelitian ini adalah untuk menemukan model pemberdayaan ekonomi keluarga miskin terintegrasi dengan wirausaha produk ikan di Kecamatan Kretek Kabupaten Bantul DIY yang mempunyai tujuan khusus, yaitu: (1) menemukan permasalahan ekonomi dan nonekonomi yang menjadi kendala keluarga miskin di wilayah Kretek Bantul Yogyakarta; (2) menemukan cara mengembangkan model pemberdayaan ekonomi keluarga miskin yang terintegrasi dengan wirausaha produk ikan sehingga dapat meningkatkan sikap dan keterampilan wirausaha keluarga di Kretek Bantul; dan (3) menghasilkan model pemberdayaan ekonomi keluarga miskin yang berupa buku panduan dan perangkat pembelajaran yang praktis untuk dilaksanakan.

Suharto (2005) menjelaskan bahwa pemberdayaan (empowerment) berasal dari kata 'power' (kekuasaan atau keberdayaan). Melalui pemberdayaan, masyarakat akan memperoleh pemahaman dan memiliki kendali terhadap kekuatan ekonomi, politik, dan sosial agar mening-katkan posisi mereka di tengah masyarakat (Kindervater, 1979:13). Oleh karena itu, dapat dikatakan bahwa pemberdayaan merupakan upaya untuk meningkatkan potensi diri kelompok masyarakat sehingga mereka memiliki kekuatan dan selanjutnya memiliki posisi tawar di lingkup masyarakat yang lebih luas.

Meredith (2005) menyatakan bahwa wirausaha adalah orang-orang yang mempunyai kemampuan melihat dan menilai kesempatan usaha serta mengumpulkan sumber daya yang dibutuhkan guna mengambil keuntungan dan mengambil tindakan yang tepat untuk memastikan kesuksesan. Para wirausaha merupakan pengambil resiko yang telah diperhitungkan. Mereka bergairah menghadapi tantangan. Wirausaha meng-hindari situasi resiko rendah karena tidak ada tantangan dan menjauhi situasi resiko tinggi, dalam rangka meraih keberhasilan. Mereka menyukai tantangan yang dapat diatasi.

Kewirausahaan menurut Kristanto (2009), yaitu seni, perilaku, sifat, ciri, dan watak seseorang, yang memiliki kemampuan dalam mewujudkan gagasan inovatif ke dalam dunia nyata secara kreatif. Jadi, terdapat tiga indikator kewirausahaan, yaitu berpikir sesuatu yang baru (kreatif), bertindak melakukan sesuatu yang baru (inovatif) dan berkeinginan menciptakan nilai tambah (value added). Oleh karena itu, seorang wirausahawan harus memiliki kemampuan untuk selalu berpikir sesuatu yang baru, melakukan sesuatu yang baru, dan berkeinginan menciptakan nilai tambah.

Kotler \& Keller (2007) menyatakan, pemasaran adalah sesuatu proses sosial yang di dalamnya individu dan kelompok mendapatkan apa yang mereka butuhkan dengan menciptakan, menawarkan, dan secara bebas mempertukarkan produk yang bernilai dengan pihak lain. Strategi adalah cara untuk mencapai tujuan. Strategi tergambar dalam bentuk cara atau pathway (pedoman dalam pikiran) untuk mencapai tujuan yang diharapkan.

\section{METODE}

Penelitianinimenggunakan prosedur Research and Development (R\&D) (Borg \& Gall, 2003) dengan target terumuskannya model pemberdayaan masyarakat miskin terintegrasi dengan wirausaha produk ikan. Penelitian ini diawali dengan: (1) mengkaji berbagai literatur, peraturan, pedoman penyelenggaraan pembelajaran, dan survei; (2) kunjungan ke lokasi, Dinas Pendidikan Kabupaten Bantul dan PKBM; dan (3) diskusi 
dengan pelaksanaan program, tutor, praktisi, dan masyarakat yang selama ini dilakukan untuk mengamati pelaksanaan program pemberdayaan masyarakat miskin. Hasil dari tiga kegiatan pada tahap pertama merupakan bahan kajian untuk membuat perencanaan kegiatan. Berbagai masukkan tersebut diseminarkan dengan melibatkan para pakar dan praktisi untuk mendapatkan tanggapan tentang model yang akan dikembangakan. Tahapan selanjutnya adalah mengadakan workshop dan Focus
Group Discussion (FGD) untuk merancang model pemberdayaan masyarakat miskin terintegrasi dengan wirausaha produk ikan. Hasil perumusan model kemudian divalidasi oleh kelompok ahli. Setelah validasi, tahap selanjutnya adalah revisi yang menghasilkan model pemberdayaan masyarakat. langkah-langkah penelitian yang lebih rinci dapat dilihat pada Gambar 1.

Program utama dalam penelitian ini adalah memberdayakan masyarakat miskin melalui pendidikan kewirausaha-

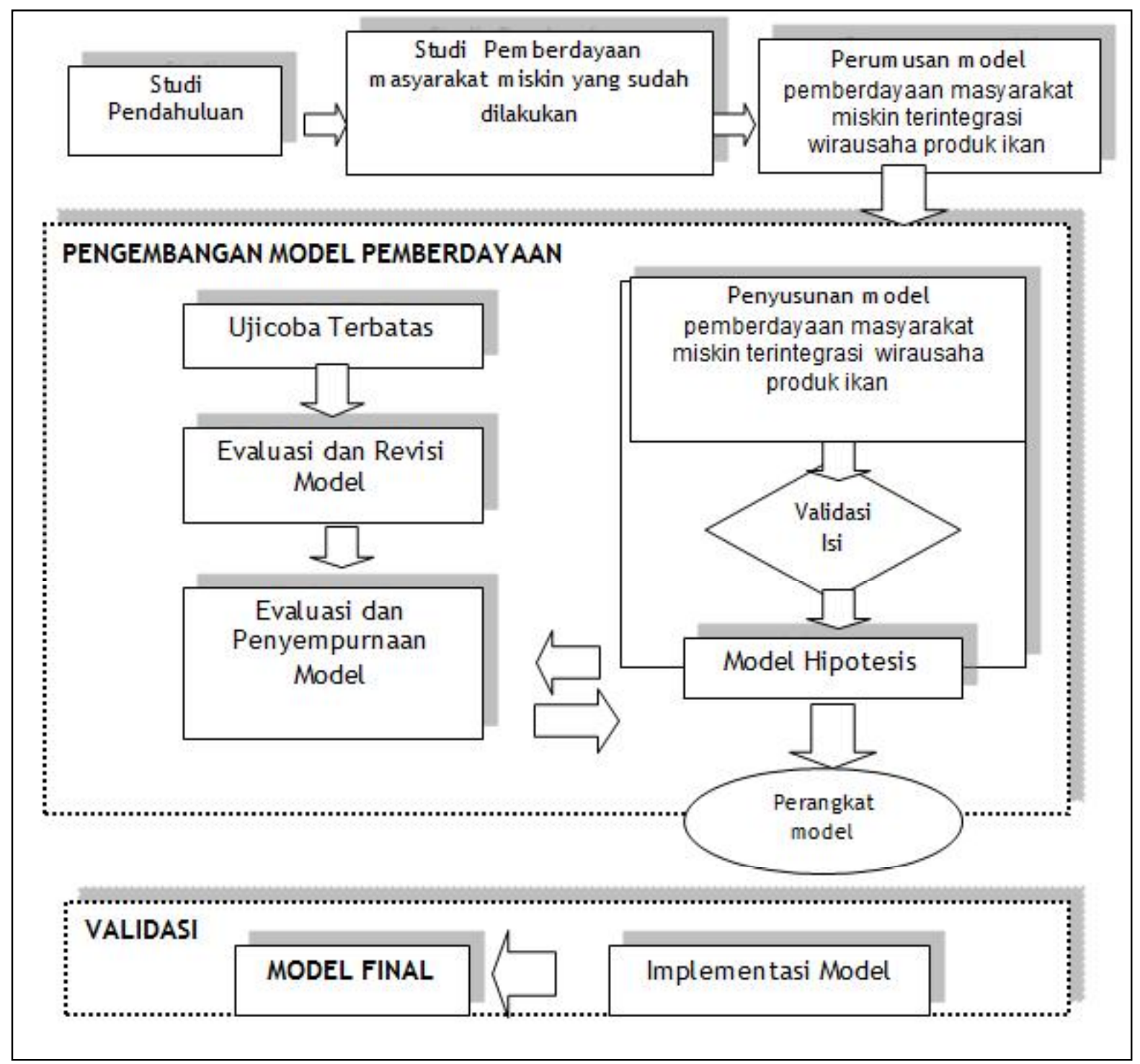

Gambar 1. Tahapan Penelitian 
an produk ikan. Kepada para peserta pelatihan diajarkan teori kewirausahaan yang mencakup: sikap personal dan sosial wirausaha, manajerial usaha kecil, kemampuan berpikir logis, keterampilan berwirausaha, dan keterampilan produksi olahan makanan berbasis ikan yang selanjutnya berdampak pada peningkatan penghasilan warga. Setelah pelatihan, peserta dibimbing untuk menjalankan usaha produktif yang dikehendakinya serta dilakukan pendampingan sosial yang mencakup: (1) stimulasi permodalan; (2) pembentukan kelompok sebagai mekanisme kelembagaan untuk mengorganisasi dan melaksanakan kegiatan pengembangan masyarakat di desa atau kelurahan mereka; (3) memotivasi kelompok untuk terlibat dalam kegiatan peningkatan pendapatan; dan (4) pengembangan jaringan kerja sama. Lokasi penelitian dilakukan di wilayah Kabupaten Bantul Yogyakarta. Tempat yang dipilih berdasarkan karakteristik penelitian adalah daerah dengan tingkat kemiskinan tinggi. Daerah tersebut adalah Kecamatan Kretek Kabupaten Bantul.

Sumber data dalam penelitian ini diperoleh dari kajian-kajian literatur, kajian peraturan, dan informasi dari lapangan (pelaksanaan program). Selanjut-nya untuk mematangkan konsep model pemberdayaan masyarakat miskin melalui wirausaha produk ikan dilakukan FGD. Dalam kegiatan ini peneliti mendatangkan pakar dan mitra sebagai narasumber yang dapat memberi tanggapan tentang model pemberdayaan masyarakat miskin melalui wirausaha produk ikan. Teknik pengumpulan data dalam penelitian ini dibagi menjadi dua bagian. Data kuantitatif dikumpulkan dengan menggunakan dokumentasi dan observasi. Sedangkan data kualitatif dikumpulkan secara terus menerus lalu diklarifikasi berdasarkan tujuannya. Data tersebut kemudian dianalisis secara deskriptif naturalistik dan deskriptif analitik.

\section{HASIL DAN PEMBAHASAN \\ Prapengembangan (Rumusan Pem- berdayaan Ekonomi Masyarakat Kecamatan Kretek Kabupaten Bantul)}

Kegiatan prapengembangan berupa rumusan pemberdayaan ekonomi masyarakatKecamatanKretekKabupaten Bantul dilakukan melalui kegiatan pertama yakni dengan mengkaji berbagai literatur, peraturan, pedoman penyelenggaraan pembelajaran, dan survei atau kunjungan kelokasi. Dalam usaha mencari responden peneliti menghubungi Kepala Bagian Kesejahteraan Masyarakat (KESRA) serta Pimpinan PKBM Mandiri Kecamatan Kretek Bantul. Dari hasil diskusi dengan pelaksana program, tutor, praktisi, dan masyarakat diketahui bahwa program pemberdayaan masyarakat miskin yang dilakukan selama ini adalah berupa pembinaan berupa pelatihan tentang bagaimana memasarkan produk secara sederhana, tanpa adanya tindak lanjut setelah pelatihan berlangsung.

Tahap kedua adalah mengumpulkan responden dari hasil rekomendasi kepala bagian KESRA Kecamatan Kretek Bantul yang dilaksanakan di Rumah Makan Bagong Pantai Depok Kretek Bantul. Jumlah responden yang hadir sebanyak 21 orang. Responden semuanya perempuan dengan rentang usia antara 20 tahun hingga 47 tahun. Usaha atau pekerjaan responden sebagai anggota koperasi, pekerja pada rumah makan, usaha menjual produk ikan seperti: ikan goreng, peyek jingking, dan peyek rebon. Pekerjaan responden, sebanyak 12 orang sebagai buruh atau tenaga kerja warung makan, 5 orang sebagai penjual dan produsen masakan atau olahan 
ikan dan 4 orang sebagai karyawan Kelompok Usaha Bersama (KUB). Lama bekerja mereka berkisar antara 1 tahun hingga 20 tahun. Pendapatan sebagain besar responden tidak menentu. Sebagai penjual dan pembuat masakan dari ikan berpenghasilan $\mathrm{Rp} 500.000$ perbulan. Sebagai karyawan KUB berpenghasilan Rp 35.000 setiap harinya. Sedangkan sebagai buruh atau tenaga kerja berpenghasilan tidak menentu. Secara rinci profil jenis pekerjaan responden disajikan pada Tabel 1 berikut ini.

Tabel 1. Profil Responden

\begin{tabular}{rrl}
\hline \multicolumn{2}{c}{ Responden } & \multicolumn{1}{c}{ Pekerjaan } \\
\cline { 1 - 2 } Jml & \multicolumn{1}{c}{$\%$} & \\
\hline 12 & 57.14 & $\begin{array}{l}\text { Buruh atau tenaga kerja } \\
\text { pada warung makan }\end{array}$ \\
5 & 23.80 & $\begin{array}{l}\text { Penjual dan produsen } \\
\text { masakan ikan }\end{array}$ \\
4 & 19.04 & $\begin{array}{l}\text { Karyawan KUB } \\
\text { (Kelompok Usaha } \\
\end{array}$ \\
& & Bersama) \\
\hline
\end{tabular}

Berdasarkan hasil diskusi dengan responden diketahui bahwa berkaitan dengan keadaan kerja responden terdapat beberapa kendala dan faktor pendukung. Bagi responden sebagai buruh atau tenaga kerja pada warung makan dengan kendala penghasilan yang tidak menentu, belum pernah mengikuti pembinaan ataupun pelatihan. Sedangkan sebagai faktor pendukung adalah kemauan atau motivasi untuk mengembangkan diri yang tampak cukup tinggi. Bagi responden sebagai penjual dan produsen masakan ikan dengan kendala tempat yang kurang mendukung, yakni sejak pasar pindah tempat sering sepi pembeli dan penjual terutama warung makan tidak diperbolehkan memiliki persediaan ikan sendiri, tetapi setiap ada pesanan harus membeli ke pasar ikan. Sebagai faktor pendukung adalah sebagian besar resonden memiliki motivasi yang cukup, bahkan terdapat seorang yang betul-betul ingin sekali mengembangkan usahanya, termasuk responden yang sebagai karyawan KUB juga memiliki keinginan untuk mengembangkan diri agar lebih meningkat penghasilanya.

Sebagai dasar menentukan kegiatan pendidikan dan pelatihan, maka dilakukan diskusi dengan responden. Dari hasil diskusi diketemukan bahwa terdapat limbah ikan yang tidak dimanfaatkan yakni kepala udang yang cukup banyak pada setiap rumah makan. Apabila dikumpulkan setiap hari limbah itu dapat mencapai $60 \mathrm{~kg}$. Potensi bahan pangan lain yang belum dimanfaatkan secara maksimal adalah potensi umbiumbian, yaitu singkong. Dari dasar diskusi dengan peserta kemudian disepakati dan dibuat rencana kegiatan berdasarkan permintaan dan permasalahan yang dihadapi peserta dan selanjutnya merupakan bahan kajian untuk membuat perencanaan kegiatan.

\section{Pengembangan (Penyusunan Panduan Pemberdayaan Ekonomi Keluarga Miskin)}

Data ataupun masukan dari peserta dan berbagai literatur tentang pemberdayaan keluarga miskin yang telah dipelajari pada tahap prapengembangan menjadi dasar dalam mengembangkan model pemberdayaan keluarga miskin di Kecamatan Kretek Bantul DIY. Pengembangan model pemberdayaan keluarga miskin dimulai dengan tahap perancangan (design), yaitu merencanakan tujuan pembelajaran yang ingin dicapai yang selanjutnya menjadi dasar dalam pengembangan instruksional. Tahap selanjutnya adalah 
menyusun rancangan model serta instrumen penelitian. Model diwujudkan dalam bentuk buku panduan yang dilengkapi dengan perangkat, yakni kurikulum, job sheet, dan hand out. Instrumen keefektifan model divalidasi oleh ketua PKBM dan Kepala Bagian Kesejahteraan Masyarakat (KESRA) Kecamatan Kretek Bantul.

Buku panduan model pemberdayaan keluarga miskin berisikan komponen sebagai berikut: (1) Teori pendukung yang mendasari pengembangan model pemberdayaan keluarga miskin. Pada bagian ini dikembangkan teori pembelajaran yang terkait dengan pendidikan untuk orang dewasa atau andragogi. Konsep lain adalah konsep pelaksanaan pembelajaran kewirausahaan; Gambaran aktivitas pemberdayaan melalui pembelajaran kewirausahaan untuk keluarga miskin dengan pendekatan andragogi; dan (3) Tahapan pemberdayaan keluarga miskin yang berupa pendidikan dan pelatihan yang mencakup rencana pelatihan, persiapan pelatihan, pelaksanaan pelatihan, penutupan pelatihan, pemantauan, dan evaluasi pelatihan.

Job sheet (lembar kerja) dirancang untuk membantu mempermudah peserta DIKLAT dalam melaksanakan praktik pengolahan makanan. Job sheet berupa resep masakan yang akan dipraktikkan. Hand out dirancang sebagai materi pelatihan yang berbentuk teori. Hand out yang dibuat adalah materi kewirausahaan yang berisi materi motivasi peserta dan contoh pembukuan secara sederhana.

Dalam kegiatan pengembangan juga dibuat instrumen untuk menilai buku panduan untuk mengetahui cakupan isi panduan, kedalaman isi panduan, organisasi isi panduan, bahasa dan tanda baca, serta referensi. Adapun hasil validasi buku panduan yang disusun dapat dilihat pada Tabel 2.

Tabel 2. Hasil Telaah Buku Panduan

\begin{tabular}{|c|c|c|}
\hline No & Komponen & Saran Perbaikan \\
\hline 1 & $\begin{array}{l}\text { Cakupan isi } \\
\text { panduan }\end{array}$ & \\
\hline 2 & $\begin{array}{l}\text { Kedalaman } \\
\text { isi panduan }\end{array}$ & $\begin{array}{l}\text { Perlu dicermati } \\
\text { macam dan jenis } \\
\text { pelatihan }\end{array}$ \\
\hline 3 & $\begin{array}{l}\text { Organisasi } \\
\text { isi panduan }\end{array}$ & $\begin{array}{l}\text { Pasca pelatihan } \\
\text { tidak cukup } \\
\text { sampai evaluasi, } \\
\text { tetapi sampai } \\
\text { pendampingan }\end{array}$ \\
\hline 4 & $\begin{array}{l}\text { Bahasa dan } \\
\text { tanda baca }\end{array}$ & $\begin{array}{l}\text { Beberapa penulisan } \\
\text { ada yang salah. } \\
\text { Penggunaan bahasa } \\
\text { banyak yang tidak } \\
\text { sesuai EYD }\end{array}$ \\
\hline 5 & $\begin{array}{l}\text { Daftar } \\
\text { referensi }\end{array}$ & \\
\hline
\end{tabular}

Selain validasi dari ahli juga diberikan masukan pada saat seminar kemajuan atau monitoring secara internal dan eksternal hasil penelitian yang dilaksanakan oleh Lembaga Penelitian dan Pengabdian Masyarakat UNY. Setelah validasi, tahap selanjutnya adalah revisi yang menghasilkan model pemberdayaan masyarakat. Pada saat proses penyusunan model panduan pemberdayaan ekonomi keluarga miskin di Kecamatan Kretek Bantul juga sekaligus dilakukan kegiatan pembinaan, yakni pemberian materi motivasi berwirausaha, pelatihan membuat krupuk kepala udang serta dilaksnakan kunjungan industri pada sentra industri peyek di Dusun Pelembadu Kecamatan Imogiri. Hal tersebut dilakukan untuk dijadikan daya tarik bagi responden agar 
setiap kali pertemuan selain peneliti akan mendapatkan informasi dari responden, responden juga mendapatkan pengetahuan dan keterampilan untuk meningkatkan keberdayaannya.

\section{Perangkat Model Pemberdayaan Eko- nomi yang Praktis dan Efektif}

Dalam rangka menanggulangi pengangguran dan kemiskinan, terutama di Indonesia, peranan ekonomi keluarga menjadi penting dan menjadi program inti kebijakan. Daya tahan ekonomi di suatu daerah, sangat ditentukan oleh kokohnya ekonomi keluarga. Kemiskinan yang terjadi di berbagai wilayah perdesaan disebabkan oleh lemahnya pertahanan ekonomi keluarga. Kuatnya daya tahan ekonomi keluarga akan menentukan kekuatan ekonomi suatu wilayah.

Berbagai cara telah dilakukan pemerintah Indonesia untuk menanggulangi kemiskinan dan pengangguran melalui berbagai program dan berbagai lembaga. Program pemberdayaan dapat berupa program pendidikan dan pelatihan. Agar program dapat tercapai secara maksimal maka harus direncanakan secara mantap. Agar suatu program pendidikan dapat mencapai sasaran, maka pemerintah Indonesia menentapkan adanya standar pendidikan, di antaranya standar kompetensi lulusan, standar proses, serta standar tenaga pendidik dan kependidikan (PP RI No. 32 Tahun 2013 tentang Perubahan atas Peraturan Pemerintah No. 19 Tahun 2005 tentang Standar Nasional Pendidikan).

Model pemberdayaan keluarga miskin yang berupa buku panduan dan perangkatnya yang telah disusun diharapkan dapat digunakan sebagai pedoman bagi penyelenggaraan program pendidikan masyarakat. Harapannya penyelenggaraan pendidikan dan pe- latihan yang diberikan pada pendidikan untuk masyarakat miskin juga mengikuti langkah-langkah mendekati ketentuan yang telah ditetapkan pada Standar Nasional Pendidikan.

Kegiatan prapengembangan berupa rumusan pemberdayaan ekonomi masyarakat Kecamatan Kretek Kabupaten Bantul dilakukan melalui kegiatan pertama yakni mengkaji berbagai literatur, peraturan, pedoman penyelenggaraan pembelajaran, serta survei atau kunjungan ke lokasi responden yang berdasarkan hasil rekomendasi kepala bagian KESRA Kecamatan Kretek Bantul, sebanyak 21 orang dan semuanya perempuan dengan rentang usia antara 20 tahun hingga 47 tahun. Memang, perempuan menjadi korban kemiskinan yang paling besar. Data MDG's (2010) melaporkan, dari sepertiga penduduk dunia yang hidup di bawah garis kemiskinan, sekitar 70\%-nya adalah perempuan. Jumlah penduduk miskin di Indonesia mencapai 32,53 juta jiwa $(14,15 \%), 70 \%$ dari mereka adalah perempuan. Kemiskinan yang menimpa perempuan Indonesia, boleh jadi disebabkan oleh banyak faktor. Angka buta aksara perempuan sebesar 12,28\%, sedangkan laki-laki 5,84\%. Dalam bidang kesehatan, status gizi perempuan masih merupakan masalah utama.Angka kematian ibu (AKI) juga masih sangat tinggi, yaitu sebesar 248 per 100.000 kelahiran hidup. Di bidang ekonomi, tingkat partisipasi angkatan kerja (TPAK) laki-laki jauh lebih tinggi $(86,5 \%)$ daripada perempuan $(50,2 \%)$.

Pekerjaan responden sebagian besar adalah sebagai buruh atau tenaga kerja warung makan, kemudian sebagai penjual dan produsen masakan atau olahan ikan dan sebagai karyawan Kelompok Usaha Bersama (KUB). Pendapatan sebagain besar responden tidak menentu. Namun 
responden tampak telah memiliki kesadaran yang tinggi dalam kepemilikan jumlah anak. Semua responden tidak memiliki banyak anak, karena telah sadar penting dan beratnya memiliki anak banyak. Lama bekerja rata-rata 8 jam sehari. Penjual dan pembuat masakan dari ikan berpenghasilan $\mathrm{Rp} 500.000$ perbulan. Sebagai buruh atau tenaga kerja bisa berpenghasilan tidak menentu. Sedangkan sebagai karyawan KUB berpenghasilan Rp 35.000 setiap harinya. Dari hasil diskusi tampak mereka sangat memerlukan peningkatan pengahasilan yang dapat meningkatkan kesejahteraan keluarga mereka.

Sebagaian besar responden tampak antusias mengembangan taraf hidup dengan meningkatnya pendapatan mereka, namun karena kurangnya pengetahuan dan pengalaman mereka, produk yang dihasilkan pun masih kurang bagus, seperti peyek yang masih keras, ikan goreng yang kurang enak, penampilan yang kurang menarik, dan kemasan yang belum dipikirkan. Sebagai dasar menentukan kegiatan pendidikan dan pelatihan, perlu dilakukan diskusi dengan responden untuk menentukan pemecahan masalah sehingga ditemukan materi atau bahan pelatihan yang sesuai dengan kebutuhan. Yang tidak kalah penting lagi adalah penentuan jadwal kegiatan pelatihan, karena sebagaian besar responden sebagai buruh atau tenaga kerja, sehingga jadwal kegiatan pelatihan harus betul-betul disepakati bersama di awal kegiatan. Pelaksanaan kegiatan juga dijadwalkan dengan rentang waktu yang tidak terlalu lama, agar tidak lupa.

\section{SIMPULAN}

Berdasarkan hasil penelitian dan pembahasan, dapat dirumuskan beberapa simpulan sebagai berikut: (1) menghasilkan rumusan permasalahan ekonomi dan nonekonomi yang menjadi kendala keluarga miskin di wilayah Kretek Bantul Yogyakarta, yaitu ditemukan kebutuhan pengembangan produk, dengan memanfaatkan potensi lokal yaitu singkong dan kulit kepala udang (ratarata $60 \mathrm{~kg}$ perhari); (2) menemukan cara mengembangkan model pemberdayaan ekonomi keluarga miskin yang terintegrasi dengan wirausaha produk ikan sehingga dapat meningkatkan sikap dan keterampilan wirausaha keluarga di Kretek Bantul, dengan membuat model pemberdayaan berupa buku panduan, perangkat pembelajaran (RPP, kurikulum, dan instrumen); (3) menghasilkan model pemberdayaan ekonomi keluarga miskin yang berupa buku; dan (4) panduan dan menghasilkan perangkat pembelajaran yang praktis untuk dilaksanakan.

Berdasarkan pada simpulan di atas, dapat dikemukakan saran berikut ini. Untuk membantu masyarakat miskin di wilayah Kretek Bantul melalui penelitian ini hendaknya dikembangkan kemampuan berwirausaha dalam skala kecil atau mikro melalui pendidikan kewirausahaan. Konsep kewirausahaan bagi masyarakat miskin diwilayah Kretek kabupaten Bantul yang akan diterapkan terlebih dahulu dibuat dalam bentuk modul pembelajaran kewirausahaan dan dijabarkan ke dalam materi-materi pelatihan secara lebih sederhana disesuaikan dengan kebutuhan belajar masyarakat. Untuk meneruskan tujuan penelitian hendaknya dikembangkan buku panduan dan perangkat pemberdayaan agar lebih efektif pada objek yang lainya.

\section{DAFTAR PUSTAKA}

Borg, R.W. \& Gall, D.M. (2003). Education Research: An Introduction Seventh Edition. New York: Logman inc. 
Davis, K. \& Newstrom, J. (1996). Perilaku dalam Organisasi. Edisi Tujuh. Jakarta: Erlangga.

Dinas Kelautan dan Perikanan Tahun 2012. Profil Kelautan dan Perikanan Kabupaten Bantul.

Kindervater, S. (1979). National Education as An Empowering Process. Massachussetts: Center for International Education University of Massachussetts.

Kotler, P. \& Keller, K.L. (2007). Manajemen Pemasaran. Edisi Kedua Belas. Jilid 1, dialihbahasakan oleh Benjamin Molan, Jakarta: PT Indeks.

Kristanto, H. (2009). Kewirausahaan Entrepreneurship Pendekatan Manajemen dan Praktik. Yogyakarta: Graha Ilmu.
Maliki, Z. (2010). Sosiologi Pendidikan. Yogyakarta: Gadjah Mada University Press.

Meredith, G.G. (2005). The Practice of Entreprenership. Geneva: International Labor Organization.

Peraturan Pemerintah RI Nomor 32 Tahun 2013 tentang Perubahan atas Peraturan Pemerintah Nomor 19 Tahun 2005 tentang Standar Nasional Pendidikan.

Suharto, E. (2005). Membangun Masyarakat Memberdayakan Rakyat: Kajian Strategis Pembangunan Kesejahteraan Sosial \& Pekerjaan Sosial. Bandung: PT Rafika Aditama.

Undang-Undang RI Nomor 20 Tahun 2003 tentang Sistem Pendidikan Nasional. 